\title{
Abnormalities in semen analysis among male partners of infertile couples: a study in a tertiary care level hospital of West Bengal, India
}

\author{
Nandini Bhaduri (Bhattacharyya) ${ }^{1}$, Aditya Prasad Sarkar ${ }^{2}$, \\ Nikhilesh Dewasi ${ }^{3}$, Tapan Kumar Ghosh ${ }^{1}$
}

\author{
${ }^{1}$ Department of Pathology, B S Medical College, Bankura-722102, West Bengal, India \\ ${ }^{2}$ Department of Community Medicine, B S Medical College, Bankura-722102, West Bengal, India \\ ${ }^{3}$ Department of Pathology, Burdwan Medical College, Burdwan-713104, West Bengal, India
}

Received: 23 November 2014

Accepted: 20 December 2014

\section{*Correspondence:}

Dr. Aditya Prasad Sarkar,

E-mail: dradityaprasadsarkar@gmail.com

Copyright: () the author(s), publisher and licensee Medip Academy. This is an open-access article distributed under the terms of the Creative Commons Attribution Non-Commercial License, which permits unrestricted non-commercial use, distribution, and reproduction in any medium, provided the original work is properly cited.

\begin{abstract}
Background: The prevalence of infertility in the general population is $15 \%-20 \%$. Of this, the male factor is responsible for $20 \%-40 \%$. Analysis of semen is the most important diagnostic tool for evaluation of role of males in infertility. The study was conducted to determine the abnormalities in semen among male partners in infertile couples. Methods: A descriptive study with cross-sectional design among male partners of infertile couples was conducted in the laboratory of the Department of Pathology at Burdwan Medical College, Burdwan in West Bengal during August 2011 to July 2012. Analysis of semen was done for semen volume, sperm number, sperm motility and presence of other cells.

Results: $7.45 \%$ samples were of inadequate quantity. $19.87 \%$ of cases had oligozoospermia, $12.42 \%$ had azoospermia and $4.35 \%$ of males had asthenozoospermia. Pus cells were found in $12.42 \%$ cases.

Conclusions: Majority of the cases of infertility in males is due to oligozoospermia followed by azoospermia while less sperm motility or less amount of semen are also responsible in some cases.
\end{abstract}

Keywords: Semen analysis, Male infertility, Tertiary care hospital

\section{INTRODUCTION}

Infertility is defined as a disease of the reproductive system defined by the failure to achieve a clinical pregnancy after 12 months or more of regular unprotected sexual intercourse. ${ }^{1}$ It is considered as social stigma in developing countries like India. The prevalence of infertility in the general population is $15 \%-20 \%$. Of this, the male factor is responsible for $20 \%-40 \% .^{2}$ In Indian couples seeking treatment, the male factor is the cause in approximately $23 \% .^{3}$ Analysis of semen is the most important diagnostic tool for evaluation of role of males in infertility. Semen has two major quantifiable attributes a) the total number of spermatozoa which reflects sperm production by the testes and the patency of the post- testicular duct system and b) the total fluid volume contributed by the various accessory glands which reflects the secretary activity of the glands. ${ }^{4}$ Recently semen quality is reported to have been declining in the world. But study in North India revealed no change in quality whereas study in South India showed a decline in the quality of semen. ${ }^{5,6}$ Literature review could not reveal such study in this part of country. With this background the study was conducted to determine abnormalities in semen among male partners in infertile couples.

\section{METHODS}

It was a descriptive study with cross-sectional design. The study was conducted in the laboratory of the 
Department of Pathology at Burdwan Medical College, Burdwan in West Bengal during August 2011 to July 2012. The study population included male partners of infertile couples. The cases were advised to observe abstinence from intercourse for 3-4 days. Semen samples were collected aseptically after masturbation in sterile wide-mouthed bottles within the hospital premises or home and delivered to the laboratory within one hour of collection. Analysis of semen was done for semen volume, sperm number, sperm motility and presence of other cells. The following criteria were used for interpretation of results of analysis: lower reference limit for sperm concentration as $15 \times 10^{6}$ spermatozoa per $\mathrm{ml}$ and lower reference limit for total motility (progressive + non-progressive) as $40 \%{ }^{4}$

\section{RESULTS}

Out of 161 semen samples studied, $7.45 \%$ were of inadequate quantity i.e. less than $1.5 \mathrm{ml}$ (Table 1). 19.87 $\%$ of cases had oligozoospermia (less than the reference level i.e. $1.5 \mathrm{million} / \mathrm{ml}$ ) while $12.42 \%$ had azoospermia. $4.35 \%$ of males had asthenozoospermia i.e. sperm motility less than the reference level i.e. $40 \%$. In $12.42 \%$ samples pus cells were found. All the 161 samples had alkaline $\mathrm{pH}$ and normal morphology of sperms. Size and particulars of testis were normal in all cases.

Table 1: Characteristics of semen samples $(n=161)$.

\begin{tabular}{|lll|}
\hline Characteristics & Number & Percentage \\
\hline Semen volume $<1.5 \mathrm{ml}$ & 12 & 7.45 \\
\hline Oligozoospermia & 32 & 19.87 \\
\hline Azoospermia & 20 & 12.42 \\
\hline Sperm motility $<40 \%$ & 7 & 4.35 \\
\hline Presence of pus cell & 20 & 12.42 \\
\hline
\end{tabular}

\section{DISCUSSION}

The present study was conducted to determine the abnormalities in semen samples for detection of male infertility. In a study at Bangalore $6 \%$ cases had semen volume of less than $2 \mathrm{ml}^{7}$ A study conducted at rural Central India revealed that $22 \%$ of cases had semen volume of less than $2 \mathrm{ml}^{8}{ }^{8} 33.8 \%$ males had semen volume less than normal in Nigeria study. ${ }^{9}$ Proportion of cases with azoospermia was less in Bangalore study ${ }^{7}$ whereas $25 \%$ cases had sperm count $<20$ million $/ \mathrm{ml}$ in the study in Central India. ${ }^{8}$ The proportion of oligozoospermia is similar to the finding of the study in Bangladesh. ${ }^{10}$ In one Nigerian study the proportion of cases of azoospermia was less ${ }^{9}$ but in one study it was much more than the present study. ${ }^{11}$ A study in Ibadan revealed similar proportion of azoospermia cases. ${ }^{12}$

Proportion of azoospermia cases were found to be similar in Bangalore study. ${ }^{7}$ A high proportion of cases were having azoospermia in Bangladesh study ${ }^{10}$ while that was less in one Nigerian study ${ }^{11}$ and much less in another study at Nigeria. ${ }^{11}$ Only $6.7 \%$ cases suffered from azoospermia in Ibadan. ${ }^{12}$ Less Motility of sperms were found to be more in Bangalore study. ${ }^{10}$ Sperms were found to have less motility in $10 \%$ cases in Bangladesh. Presence of pus cells was reported in $33 \%$ of cases in rural Central India study. ${ }^{8}$

Abnormal result in semen analysis contributes to infertility in males to a great extent. The present study revealed that majority of the cases of infertility in males is oligozoospermia followed by azoospermia while less sperm motility or less amount of semen are also responsible in some cases.

\section{Funding: No funding sources \\ Conflict of interest: None declared \\ Ethical approval: Not required}

\section{REFERENCES}

1. Zegers-Hochschild F, Adamson GD, de Mouzon J, Ishihara O, Mansour R, Nygren K, et al. ICMART and WHO international committee for monitoring assisted reproductive technology (ICMART) and the World Health Organization (WHO) revised glossary of ART terminology, 2009. Fertil Steril. 2009 Nov;92(5):1520-4.

2. Sigman M, Lipshultz LI, Howards SS. Evaluation of the subfertile male. In: Lipshultz LI, Howards SS eds. Infertility in the Male. 4th ed. St. Louis, Missouri: Mosby-Year Book; 1997: 173.

3. Zargar AH, Wani AI, Masoodi SR, Laway BA, Salahuddin M. Epidemiologic and etiologic aspects of primary infertility in the Kashmir region of India. Fertil Steril. 1997;68:637-43.

4. WHO. WHO laboratory manual for the examination and processing of semen. In: WHO, eds. WHO Manual. 5th ed. Geneva: WHO; 2010.

5. Marimuthu P, Kapilashrami MC, Misro MM, Singh G. Evaluation of trend in semen analysis for 11 years in subjects attending a fertility clinic in India. Asian J Androl. 2003;5:221-5.

6. Adiga SK, Jayraman V, Kalthur G, Upadhya D, Kumar P. Declining semen quality among south Indian infertile males- a retrospective study. J Hum Repro Sci. 2008;1:15-8.

7. Joshi P, Gopal N, Bhat V. Study of semen analysis patterns in infertile males. Int J Pharm Bio Sci. 2011 Jan-Mar;1(1):44-9.

8. Jajoo S, Kalyani KR. Prevalence of abnormal semen analysis in patients of infertility at a rural setup in Central India. Int $\mathbf{J}$ Reprod Contracept Obstet Gynecol. 2013 Jun;2(2):161-4.

9. Onyeka CA, Ashiru OA, Duru FI, Olorunfemi OJ, Fabunmi OO, Oluwatuyi TS. Semen analysis of 263 sample men from infertility clinic in western Nigeria. West Afr J Assist Reprod. 2012;2(1):1-16.

10. Anwary SA, Alfazzaman M, Islam MR. Male subfertile patients in a tertiary hospital. Mymensingh Med J. 2011 Jan;20(1):33-9. 
11. Akinola OI, Fabamwo AO, Rabiu KA, Akinoso OA. Semen quality in male partners of infertile couples in Laos Nigeria. Int J Trop Med. 2010;5(2):37-9.

12. Adenzi RA, Olayemi O, Okunola MA, Aimakhu CO. Pattern of semen analysis of male partners of infertile couples at the university college hospital, Ibadan West Afr J Med. 2003 Sep;22(3):243-5.

DOI: $10.5455 / 2320-1770 . i j r \operatorname{rog} 20150219$

Cite this article as: Bhaduri (Bhattacharyya) N, Sarkar AP, Dewasi N, Ghosh TK. Abnormalities in semen analysis among male partners of infertile couples: a study in a tertiary care level hospital of West Bengal, India. Int J Reprod Contracept Obstet Gynecol 2015;4:100-2. 